\title{
Religious Conflict Resolution In Nigeria (Matthew 18:15-22): A Hermeneutico - Inculturation Approach
}

\author{
John A. Ottuh, Ph.D \\ Vicar: Winners Baptist Church, Effurun, P.O. Box 1214, Effurun, Delta State, Nigeria.
}

\begin{abstract}
Conflict resolution was an important aspect of the Early Church community. Conflict situation is inevitable in every society. Nigeria was faced with lingering religious conflicts especially between the Christians and the Muslims which has led to severed relationships, destruction of lives and properties worth millions of Naira. The aim of this study therefore, is to examine the cause of religious conflicts in Nigeria and call on Christians and Muslims to play a peaceful role in the community; to use the principle of conflict resolution in Matthew 18:15-22 to drive home the African spirit of brotherhood and call for a peaceful coexistence between Christians and Muslims in Nigeria. In order to do this the Inculturation Hermeneutics model was explored as a methodology. It could be seen that the cause of conflicts between Muslims and Christians is lack of the consciousness of the concept of African brotherhood and love which has showcased itself in fanaticism, intolerance and derogatory statements, political dissatisfaction and superiority complex. Though Matthew 18:15-22 is more applicable to the Christian folks in Nigeria, the lessons therein portrayed the concept of love, forgiveness, dialogue, brotherhood, and justice as instruments of conflict resolution; and could be applicable to all Nigerians. It could be assumed that peaceful coexistence between all religious adherents in Nigeria is not far fetched if the principle of brotherhood, forgiveness, dialogue, love and justice are upheld.
\end{abstract}

\section{Introduction}

Conflict expresses itself in various ways and diverse degrees and over every range of human contact. Its modes are always changing with changing social and cultural conditions. ${ }^{1}$ Some types disappear and new ones and types emerge. It is an error therefore to assume a crisis free society. Even among family members crisis is inevitable. The question is: should one allow crisis to linger on in our society? No, there must be a way out.

In Nigeria, the main religious bodies that clash most are the Christians and the Muslims. This crisis sometimes arises as a result of various religious beliefs and tenets.

What prompted this paper was the rate at which fellow human beings created in the imago Dei (image of God) are fighting and killing one another in the name of religious beliefs. Most recently many people have been reportedly dead in Plateau, Bauchi, Kaduna, and Kano states of Nigeria including children as a result of violence emanation from the dreaded Islamic sects called Boko Haram through their bombings in Bauchi, Maiduguri ${ }^{2}$ to mention but a few in the Northern part of Nigeria. ${ }^{3}$ To avoid more conflicts in the future, it is better to be proactive in resolving crisis in an amicable way. Peace is not an alien word to religious adherents in Nigeria because every major religion of the world has expressed at some point through its leaders and thinkers, a commitment to the value of peace, both in classical texts and modern reformations. ${ }^{4}$

While some believers creatively integrate their spiritual tradition and peacemaking, many others engage in some of the most destabilizing violence confronting the global community today. In order to achieve the aim of this study therefore, the inculturation hermeneutics model shall be explored in the light of Matthew 18:15-22. The inculturation hermeneutics paradigm according to Ukpong is an aspect of biblical interpretation that seeks to address socio, religious, cultural and the secular lives of the African people in the light biblical texts because all these aspects of lives in a society are interconnected. ${ }^{5}$ It could be understood that the cause of conflict between Muslims and Christians is lack of the consciousness of the concept of African brotherhood and love.

\section{Definition of Terms}

Religion: The word religion has many definitions depending on the perspective one is looking at it. According to Smith, religion is man's attempt to achieve the highest possible good by adjusting his life to the strongest and best power in the universe and this power is usually called God. ${ }^{6}$ In the opinion of John Hick, religion is human recognition of super human controlling power and especially of a personal God or gods entitled to obedience and worship. ${ }^{7}$ Also, religion according to Bouquet is a fixed relationship between the human self and some non- 
human entity, the sacred, the supernatural, the self existent, the absolute or simply God. ${ }^{8}$ All these definitions point to the issue of beliefs. Religion in the context of this paper refers to, Africa Traditional Religion, Islam and Christianity.

Conflict: Conflict may be external or internal, explicit, physical or intellectual, emotional or moral or religious. ${ }^{9}$ The word conflict according to Vine means contest, fight, combat or a struggle. ${ }^{10}$ Otite defines conflict as product of divergent interest, goals and aspirations within a defined social divergent interest, goal and aspirations within a defined physical environment. ${ }^{11}$ Also, Imasogie defines conflict as decisive or crucial point in the course of human relations whose outcome determines whether good or bad consequences will result. ${ }^{12}$

Resolution: The word resolution has many shades of meaning but in the context of the study it connotes the act of finding a solution or answer to discordant or conflict situation. Therefore, conflict is the problem while resolution is a constructive attempt to find an answer to the problem.

\section{Religious Conflicts in Nigeria}

There are three Main religious in Nigeria - Africa Traditional Religion (ATR) which is the oldest, Islam and Christianity. Have these religions been together without conflict? The answer is no. In any conflict in Nigeria being it ethnic, intertribal or intra-tribal, socio-political, or economic in nature there is religious connotation because the people involved in the conflict belong to one religion or the other. Among the adherents of these religions, conflicts are common. Sometimes, the conflicts are between Muslims and Christians or between either of the duo and the African Traditional Religious adherents. Most of these religious conflicts often lead to social economic and political upheavals with serious implications for the peace and stability of the society. ${ }^{13}$

Within the last three decades, Nigeria has witnessed a lot of conflicts ranging from intra-religious to inter- religious crisis. In December 1980, the maintatsine riot broke out in Kano. It claimed many lives in hundreds. ${ }^{14}$ In October, 1982 another maintatsine uprising in Maduguri, in which a large number of lives were lost broke out. The same riot later spread on to Kaduna and Sabon Gari area of Kano state. Also in the middle of February 1984, in Jimeta-Yola of then Gongola State another Maitatsine riot broke out and many lives were lost. $^{15}$

On $6^{\text {th }}$ of March, 1987, an inter-religious violence broke out in Kanfanchan and it later extended to Zaria and Funta (now part of Katsina State). Also, in April 1991, roasted meat, popularly known as suya caused a violent confrontation between Muslims and Christians of Tafawa Balewa Local Government Area of Bauchi State. The dispute later on spread to Bauchi town and other parts of the state. ${ }^{16}$ Violent activities cannot build Nigeria, rather it jeopardizes her political, economic and peaceful socio-religious coexistence.

Religious conflict does not only exist between Christians and Muslims it also exist between Muslim and African Traditional religious adherents. In the south western part of Nigeria, especially in yorubaland, there have been reports of conflicts between Muslims and adherent of Africa Traditional Religion. The Muslims call the idol worshippers Keferi (kafir), Olorisa (idol worshippers), Ajebo (eater of sacrifice), etc and this does not augur well between them. History has it that one Islamic preacher, Alfa bisiriyu Apalara was killed on $3^{\text {rd }}$ January, 1953 by Apalara and Awo-opa worshipers numbering 11 in the cult of oko Baba in Lagos. The eleven identified culprits were eventually sentenced to death by hanging in $14^{\text {th }}$ October, $1953 .{ }^{17}$ Also, Ajagbemokeferi an Islamic preacher of blessed memory and Ololu Masquerade in Ibadan is an example of another religious conflict. Ajagbemokeferi wanted to stop the Ololu Masquerade due to the ban placed on women not to go out on the day of Ololu outing. This matter was later settled in the court in the favour of Ajagbe.

Another case was that Alhaji Abdul-Azeez Afolabi who on his return from Arabic School in Ibadan in 1947 tends to stop the new yam tradition of Irele-calabash in Ikirun. It is believed in Ikirun that Irele_Calabsh has to taste the new yam first before other person will eat new yam. He destroyed Irele_Calabash and its content. This resulted to over four years (1963-1967) conflict and hostility. ${ }^{18}$ In May 2004, Yelwa and Shedam areas of Plateau State were engulfed in gruesome battles of which many people were killed and property worth millions of Naira were destroyed. In the same period the Jukun and Tiv of Taraba State were engaged in the feud of monarchical supremacy. ${ }^{19}$ In November, 2008 other ethnic -religious and political crises erupted in Jos and many lives and properties were destroyed. ${ }^{20}$

Most recently, a group called Boko Haran emerged in Bauchi State of Nigeria. Boko Haram opines that "Western education a non-Islamic education is a sin." ${ }^{21}$ The group was founded by Ustaz Mohammed Yusuf in 2002 in Maiduguri. In 2004 it moved to Kanamma, yobe State. ${ }^{22}$ This group also seeks to impose Shariah or Islamic Law throughout all the 36 states in Nigeria. Yusuf is said to be hostile to democracy and secular education system, vowing that this war will continue until a change comes. ${ }^{23}$ In July, 2009 the Nigerian police started investigating the group, following reports that the group was arming itself. Several leaders were arrested 
in Bauchi and this brought a clash between them and Nigerian security forces which led to the death of an estimated 700 people. ${ }^{24}$ On July 30, it was reported that Yusuf was killed during the police raid.

It was reported in February and March, 2010 that another ethno-religious conflict arose in Jos, Plateau State of Nigeria and over 500 people including women and children were Massacred. Most recently, a post election violence broke out in the North in April, 2011 when Dr.Goodluck Ebele Jonathan of the People Democratic Party (PDP), a non-muslim from the southern part of Nigeria was announced the winner of the presidential election between him and his nearest counterpart General Muhammadu Buhari of the Congress for Progressive Change Party a muslim, a violent protest breakout and many lives and properties were lost including youth corpers from the south-south geopolitical zone of Nigeria. A Similar case occurred in 1993 mainly among Yoruba when the election between M.K.O Abiola of Social Democratic Party (SDP) and Bashir Tofa of National Republican Convention (NRC) was annulled by the General Ibrahim Babagida's administration after the June 12 election. Prior to the April, 2011 elections the argument of where the presidential candidate is coming from at the point in time due to PDP zoning arrangement emerged but Nigerians opined that PDP internal arrangement as a political party can not supercede the Constitution of the Federal Republic of Nigeria. This arrangement which did not work may have contributed to the post election mayhem in the northern part of Nigeria. Religious crisis especially in the Northern part of Nigeria is no longer new but it is the desire of Nigerians to put an end to all these.

\section{Some Possible Causes of Religious Conflict in Nigeria}

A saying goes thus: "there is no smoke without fire." Religious conflicts in Nigeria have their own causes. To proffer any solution to the incessant outbreak of religious conflicts in Nigeria, it is plausible to know their causes. Here four causes shall be presented.

\section{i. Religious Fanaticism}

Religious fanaticism breeds religious conflicts. Onimhawo and Ottuh state that bigotism is another term that is closely associated with religious fanaticism and to become a religious fanatic is be wild and excessive about matters that relate to one's belief ${ }^{25}$. A religious bigot is a person who blindly and obstinately devotes his or herself to a particular creed which could be inimical to the existence and development of a mixed society. An example of this situation in Nigeria was the issue of Sharia that was raised by the Muslims during the time of the constitution drafting process in Nigeria in 1977/1978 because the Muslims from all indications wanted Nigeria as a nation to become an Islamic State. ${ }^{26}$ The secret membership of Nigeria in the organization of Islamic Conference through the instrumentality of the Muslims is another clear indication of religious fanaticism. The Christian religion on the other hand seems to want to force the Muslims, the African Traditional Religious adherents to believe their faith and practice by all means. Fanaticism can place sentiments and emotions above reason. Fanaticism is born out of ignorance and misinterpretations of the Qur'an and the Bible. In this context, it will be plausible to place Boko Haram of the Islamic sects and those Christians moved by the opium of indoctrination of none Christians as fanatics.

\section{ii Derogatory Statement and Intolerance}

This is a situation whereby particular religion is making statement that will run down the other. This could be in form of malicious attacks based on disagreement over beliefs and practices. Some times religious adherents in Nigeria vehemently attack one another due unconstructive and sweeping statements, maybe aimed at running the other down. In the process of running one another down crisis in most cases results. Umejesi ${ }^{27}$ and Larewaju $^{28}$ agree that religious intolerance in Nigeria is one of the causes of religious conflicts. The inability for religions to tolerate one another in Nigeria breeds conflicts.

\section{iii. Political Dissatisfaction}

Political dissatisfaction surfaces when one religion is given political priority over the other. For example in Nigeria before the emergence of General Olusegun Obasanjo as the president of Nigeria in 1999, there was no Christian Chapel in Aso - rock except Mosque. This type of scenario creates dissatisfaction. The attitude of some Muslims towards the emergence of Dr. Goodluck Jonathan as the winner of the April, 2011 Presidential election which many Christians including National Youth Service Coups members from the South, West and East where killed in the North arouse dissatisfaction among the Christians. The killings of over 1000 Christians including Children in Plateau State of Nigeria were also a situation that aroused dissatisfaction. One cannot totally claim that the Jos crisis affected only Christians because there were also traces of ethnic conflict of which some muslims where also killed. In a situation whereby more political offices are given to certain people from a particular religion and ethnic region than the other, can arouse dissatisfaction.

iv. Superiority Complex

Superiority Complex is a situation whereby one religion tends to play a dominant role over the others thereby arousing undue competition and rivalry. This rival, after staying for a long time may break into serious violence in an attempt to resist and defend. The religion claiming superiority may want to subjugate others and the others 
may want to resist thereby causing conflicts. A good examples of this is the proposal of Sharia in the 36 States including the Federal Capital territory of Nigeria by some Islamic religious adherents in Nigeria like the former governor of Zamfara State (Amed Yerema) and Boko Haram sect of Islam. Although, Shariah is recognized in the constitution of Nigeria, it can only be applicable to Muslims. Superiority complex is the driving force behind the absolute claims of religious truth. The Christians and Muslims are guilty of this claim. ${ }^{29}$ While one says my own is the best truth, the other says likewise.

\section{iv. Provocation}

Provocation according to the Encarta Dictionary of the English Language is something that makes somebody angry or indignant or something that incites somebody to attack somebody else. There have been some occasions where Christians call Muslims names and Muslims call Christians names. For example, the Muslims and Christians call each other unbelievers in a provocative manna. This has led to crisis several times. Even if the Christians and Muslims will have to preach to each other, it should be done in love and respect. Provocation causes annoyance and if it continues, it leads to violent reactions. All the violent reactions in Nigeria among religious adherents have led to death, lost of properties worth millions of Naira, hatred, enmity. impairment of development among other things.

\section{Matthew 18:15-22}

15 "If your brother sins against you, go and tell him his fault, between you and him alone. If he listens to you, you have gained your brother.

${ }^{16}$ But if he does not listen, take one or two others along with you, that every word may be confirmed by the evidence of two or three witnesses.

${ }^{17}$ If he refuses to listen to them, tell it to the church; and if he refuses to listen even to the church, let him be to you as a Gentile and a tax collector.

${ }^{18}$ Truly, I say to you, whatever you bind on earth shall be bound in heaven, and whatever you loose on earth shall be loosed in heaven.

${ }^{19}$ Again I say to you, if two of you agree on earth about anything they ask, it will be done for them by my Father in heaven.

${ }^{20}$ For where two or three are gathered in my name, there am I in the midst of them."

${ }^{21}$ Then Peter came up and said to him, "Lord, how often shall my brother sin against me, and I forgive him? As many as seven times?"

${ }^{22}$ Jesus said to him, "I do not say to you seven times, but seventy times seven.

\section{The Text at a Glance}

What is the text all about? Matthew 18:15-22 emphasizes the need for brothers to reconcile their differences without hesitations. No matter the enormity of the offense, the people living within a community should learn to explore all avenues for reconciliations when aggrieved.

\section{Exegesis of Matthew 18:15-22}

\section{Literary Context of Matthew 18:15-22}

It has been observed that Matthew 18:15-22 is a historical text structured within a cluster of loosely connected logia on the mutual obligations of members of the church community of Matthew to one another. ${ }^{30}$ Matthew 18:15-22 forms a periscope with the theme of Dispute settlement or conflict resolution.

Scholars agree that there are implicit and even explicit conflicts within the Matthean church community. ${ }^{31}$ The narrative on the process of conflict resolution and reconciliation enjoined on the community begins at v. 15; "if he refuses, tell the church" supposes that the dissident brother be excluded from the faith community. In this passage, there is no connotation of resorting to violence as a means of achieving conflict resolution. This is a lesson every conflict resolution theorist must learn from the Gospel of Matthew. According to Mamus, "the necessity for reconciliation as a Christian praxis enunciated in v.22 has induced many scholars to consider this unit as the centerpiece of the fourth of the five discourses that make up the major content of Matthew's Gospel. ${ }^{, 32}$ Davis and Allison sub-divided this fourth discourse into two equal units as follows:

A. 18:1-5, 6-9, and 10-14

B. $18: 15-20,21-22$ and $23-35 .^{33}$

The preceding pericope (18:10-14) give a narrative about the lost sheep and the pericope (18:23-35) after the text also gives a narrative of the unmerciful servant. All these combine depict human dignity, restoration, forgiveness, love and peaceful coexistence among humans especially those of the church community.

Socio-Historical Context of Matthew 18:15-22 
In Jesus' time the Jews especially the Pharisees were not comfortable with his teachings because His teachings seem to contradict what they have been practicing. But Jesus says that He did not come to abolish the Law (nomo) but to fulfill it (Matt. 5:17).

Though there is no direct quotation in the Old Testament that says "hate your Enemies" but concept is present in the Old Testament especially during the exodus, the conquest and in the Psalms. In this case, Matthew's church community was faced with the paradox of hate and love. Jesus' teaching during the Sermon on the Mount corrected this impression of hatred for enemies rather He says love your enemies (Matt. 5:43-45).

The most glaring conflict among the Jews which may have also appeared in Matthean faith community can be traced to the schism of the kingdom of Israel during the reign of Rehoboam the son of Solomon. Rehoboam was insensitive to disinter between right and wrong advice from the elders and youth respectively. He took the advice of the youths and this led to the splitting of the kingdom of Israel to the Northern kingdom led by Jeroboam and Southern kingdom (Judah) led by Reobaom. ${ }^{34}$.

Another conflict arose among the Jews on the issue of mix - marriages between the Hebrews and nonHebrews. Those that married spouses other than Hebrews were called Samaritans. The Jews see the Samaritans as un-pure Jews and this has brought enmity between them even to the time of Jesus. This episode can be found in Ezra 9.

The fact remains that Matthew's church community was not void of interpersonal offences or clashes yet they must be resolved. The Matthean account of the process of conflict resolution transmitted in this passage is, no doubt, sociologically situated in the Palastinian Christian community between the eighties and the early nineties AD. The community was apparently one whose several Jewish members had shortly been outlawed and ejected from official Judaism largely dominated and ruled by Pharisee group. ${ }^{35}$ In c. 80 AD, the council of Jamnia had decreed the rejection of all Jews considered being apostate of Jewish law and tradition. The Jewish sect of the time started as a protest movement rejecting the foundational belief - systems and values of the dominant establishment; then it moves on to assume and defend its egalitarian character (Manu:34). Matthew's church community in the context of the text under study was made up of Jewish Christians of which some tend to practice Jewish tradition and Jesus' teaching simultaneously.

The Old Testament background of Matthew 18:15-22 is Deuteronomic injunction on settling disputes requiring two are three witness (Deut. 19:15-21)). If the offender is remonstrant after two or three witnesses have pointed out the fault, then the entire church community agitation for reconciliation amounts to disfellowship of the adamant member.

\section{Analysis of Matthew 18:15-22}

In the context of this paper, the following keywords shall be briefly analyzed from the text: "brother, sin, church, listen, pagan and forgiveness". All these will be analyzed to resonate with the issue under discus.

i. Adelphos: one of the key themes of vv. 15-17 is adelphos and it means brother. Adelphos here as it is used in the text to denotes: a near kinsman"; in the plural, a community based on identity of origin or life; or a neighbour. ${ }^{36}$ The word adelphos carries with it embedded idea of love (agape). In Nigeria the understanding of brotherhood like in the community of Matthew will make people live together in peace regardless of gender, status, religion or ethnic affinities. When all Nigerians see one another as brothers and sisters it will be easier to resolve issues.

ii. Hamartia: Another key theme in vv. 15-17 is hamartia ( $\sin )$. In the text the Greek word reads hamartese. Hamartese (he sins) is the present active indicative of hamartia. The verb connotes transgression against the Law, God or one's neighbour. To transgress against one's neighbour indicates inter or intra - personal clash or conflict within a community. Mathew's church community was not free from clashes but refusal to make peace was regarded as a sin. In Nigeria, Christians should learn to make peace with their Muslim brothers whenever they are offended and Muslims should do same with their Christian brothers whenever they are offended too. The verb Parakouse (he hears not or he refuses to hear) indicates a situation of refusal to accept reconciliation when there is conflict (vv.17-20). If he refuses treat him as ethnikos (gentile or pagan), that is as someone who has never been a member of the brotherhood in the community. This means such a person is a deviant in the society.

iii. Ekklesia: verse 17 of the text gives the understanding of ekklesia (church or community called outs). The word ekklesia are from two words: Ek, (out of) and Klesis (to call - Kaleo). When combined it means the "call out". The word ekklesia as it is used in the text indicates a community of believers in Christ as it relates to Christianity. In a wider sense, it can also mean a community of called out people. In this sense, both Christians and Muslims in Nigeria, can be seen as people who are called out to be agents of peace and reconciliations.

iv. Aphesis: Another key theme in vv. 21-22 of the pericopy is aphesis (forgiveness). As it is used in the text, it gives the understanding of a dismissal of offence of one's neighbour from the mind. This is the only practical and spiritual step that can enhance reconciliation and peace among settlers of a community. This can also be 
applicable to both Christians and Muslims in Nigeria. Forgiveness has a very big role to play in reconciliations. When feuding parties see reasons to forgive one another it will bring stronger ties of brother in Nigeria.

In a nutshell, the core of the messages in Matthew 18:15-22 that resonate with the subject matter are adelphos (brother or brotherliness) and aphesis (forgiveness). The concept of brotherliness will give room for love (agape) and the readiness to forgive one's brother when he offends one especially during reconciliation will be possible. This will create an atmosphere of peace in the Church community and her neighbourhood. All of these when put together will enhance: the spirit of brotherhood among Nigerians irrespective of their religion and tribes, protection of lives and properties, harmonious milieus, unity, and affection.

\section{Hermeneutical Implications of Matthew 18:15-22}

From the study of the text some theological interpretations can be deduced.

i. Dialogue: This Can be used to settle conflicts among people in the church community and beyond (v. 15). Going to the brother who sins against you to talk to him about the issue shows dialogue. Violence is never the best approach to conflict resolution. Dialogue calls for understanding among conflicting parties. Dialogue was the method explored by the Early Church in resolving the dichotomy between the Jewish and Gentile Christians in the church council at Jerusalem (Acts 15:6-21). There is always a solution through genuine dialogue between the feuding parties. Christians and Muslims in Nigeria should resort to dialogue whenever there is conflict between them and other religious adherents in the community.

ii. The concept of brotherhood. The concept of brotherhood is paramount in communal coexistence (vv. 1517). The offended who goes to the offender for peace talk is indeed a good brother. The world today is becoming a global entity, because we are related in one way or the other that is either by religious, economic, political, educational or social affinity. With concept of one's neighbour as true brother or sister conflict will not linger for a long time before settlement. This concept is an indication of one family under one God. Christians should see fellow Christian as well as other religious adherents as brothers.

iii. Involvement of unbiased thirth Parties. The involvement of unbiased third party when all efforts of the two warring parties to reconcile fail is equally not out of place for conflict resolution (vv. 16-17). Matthew presents a tripartite procedure for managing conflicts. The first is a personal dialogue between the one making the correction and the offender. At this stage, it is merely a fraternal or brotherly correction intended to correct so as to help the offender acknowledge his or her fault. If the offender is unable to see his or her fault, then the intervention of big brothers is salutary. Sometimes this is not the case and so a second step of alerting few persons and if it does not work, then the involvement of the whole community. This is an indicative of an unrestrained effort to make peace. In our African lives we have a way of involving third parties to help in resolving issues. Sometimes community elders are called to help. Elders can be called upon to help resolve conflicts among people in the community.

iv. Forgiveness is paramount in the process of reconciliation (vv. 21-22). When faults linger on in the heart for too long, it triggers hatred and violence. A question was raised in the text: how many times should I forgive my offender? An answer was given by the Lord Jesus Christ: "seventy-Seven times daily" (vv. 22 NIV). This means that the frequency of forgiveness is unlimited. Forgiveness can give room for tolerance and genuine reconciliation among warring parties in a community. Forgiveness can allow love to radiate within a people in a community.

v. God should be seen as the center point of brotherhood and peace. If Muslims and Christians see God as their creator there will no room for violence between the duo. God is the owner of the community including Muslims and Christians alike (Ps. 24:1).

vi. Punishment for Deviants: The deviant members of the society are to be punished if found guilty. This implies Justice in good judgment. Every society like Nigeria has its norms and values and they carry with them prescribed sanctions for breaking them. ${ }^{37}$ In contemporary Nigeria unlawful killing of human being, cultism, truism, unlawful destruction of properties etc, being it on religious basis or other wise is against the law. When people have it in mind that they are going to be punished for violence they will be more careful in whatever they do.

\section{The African Concept of Brotherhood: A Meeting Point For Peaceful Co-Existence between Christians and Muslims in Nigeria}

The passage Matthew 18:11-22 will be so vague in Africa if it is not contextually interpreted in our African experience. The passage is applicable to Christians but can we just limit the concept of brotherhood to Christians alone? The main theme of Mathew 18:11-22 is brotherhood. The concept of brotherhood is not strange to us in Nigeria just that we seemed to throw it behind due to one sentiment or the other. The African people including Nigeria believe in brotherhood. Sometimes inter-tribal and intra-tribal conflicts arise as a result of one problem or the other but deep down in our hearts brotherhood rings louder. One reason why brotherhood is strong in Nigeria is the ties of inter-tribal or inter ethnic marriages going on in Nigeria. Another reason why 
brotherhood is strong in Nigeria among religious adherents is the inter - marriages going on between different religious adherents in the community. For example in Ogbomoso of Oyo state and Iwo of Osun State in Nigeria, it is very common to see a home made up of Christians and Muslims living together as family due to interreligious marriages. Sometimes, in Urhobo land, one still see homes where a Christian live with an African Traditional Religious adherent as husband or wife. This happen mostly when the duo where none Christians before marriage until one of them became a Christian. And being a Christian does not the Christian partner to hate none Christian partner.

Religious Conflicts arises in Nigeria most especially because we have thrown away the consciousness and spirit of our African brotherhood. Before the advent of Islam and Christianity, we where Africans; how come we became Arabs and Jews overnight? How come we became enemies over religious beliefs? African brotherhood according to Odeh is emphasized by both Islam and Christianity because the duo belief in one ancestral father (Abraham) and one God (The Almighty and Creator of all Mankind) ${ }^{38}$ Muslims and Christians can live together in peace if the Spirit of brotherhood exists predominantly in their hearts.

\section{Conclusion}

In concluding this paper we wish to ask, can conflict be totally erased from a human society or even from the Church or the Mosque? The answer is no. People in a community must learn to live together despite their diversity of origin and divergences of interest and religious tenets. What do we learn from Matthew's account about religious conflict resolution in Nigeria today? Basically, in the pericope under consideration, Matthew taught the recipient of his Gospel to see itself as a family under God. Within this context, the community of faith would be able to manage crises among its members in a godly way. This lesson remains valid for the contemporary Nigerian situation. Nigerians must first learn to see their nation as a family and themselves as members of that family, just as the Jews and Gentiles that made up the Matthean community were to see themselves as brothers and sisters, so must Nigerians see themselves.

One can constructively argue that it is human to quarrel but the virtue and wisdom thereof is the willingness to accept settlement and reconciliation within the community and beyond ${ }^{39}$. Also, to enhance settlement and reconciliation; dialogue, brotherhood spirit, forgiveness spirit and fair Justice must be pivotal.

\section{Recommendations}

To reduce or if possible to avoid religious violence in Nigeria, we wish to recommend that:

1. The Court of law in Nigeria should try culprits that perpetuate religious violence in Nigeria. According to Umejesi the 1999 constitution of Nigeria which prescribed punishment for instigators of religious violence be fully implemented so as to bring culprit to book. ${ }^{40}$ When this is done, it will stand as a deterrent to others with similar intentions.

2. Frequent religious seminars on peaceful coexistence among religious adherent in Nigeria should be organized by government, NGOs and even religious bodies to inform sound conscience.

3. All religions in Nigeria should discourage and shun violence in their approach to issues even when offended. Their adherents should be thought to embrace peace in the expression of grievances.

4. Nigerians should respect one another's religious beliefs. Being that Nigeria is multi-religious and multiracial all religions should be constitutionally allowed to practice their religion without any interference from any quarter.

5. The Government in Nigeria should be pro-active and decisive in handling violent religious conflicts and bring to book promptly all those involved in the violence no matter who they are. This will bring fear to their hearts and it will go a long way to reduce religious violence in Nigeria.

6. Religious leaders in Nigeria should inculcate in their followers in words and deeds the emphasis of brotherhood.

\section{Notes/Refrences}

[1] J.E.C. Obioma, "Religion and Conflict Resolution", M.T. Yahya, et al, (eds), Issues in the Practice of Religion in Nigeria (Jos: Nigerian Association for the Study of Religions, 2006), 255.

[2] AIT News, 27-06-2011-8pm and NewsAdmin,26, June,2011

[3] P.O.O. Ottuh, "Human Rights Abuses and Violations: The Nigerian Experience (1999-2005)", Iroro: Faculty Journal of Arts, 3, Nos. 1\&2, (2008):56

[4] H.D. Thomso, World Religion in War and Peace (Jefferson: Mifar Land, 1988), 195.

[5] J. S. Ukpong, African Biblical Interpretation: A Reader (Uyo: University of Uyo, 2006), 102

[6] H.C. Smith, "Religion", The World Book Encyclopedia Vol. 16 (Chicago: Field Enterprises Educational Corporation, 1970), 207.

[7] J. Hick, Philosophy of Religion (New Delhi: Prentice Hall of India Ltd., 1994), 2

[8] A.C. Bouquet, Comparative Religion (Middlesex: Pengium Book, 1941), 16.

[9] O.A. Adewale quoting Adventures in Literatures (New York: Harcourt, Brace, Jovanovich Publishers, 1995 ), 2. 
[10] W.E. Vine, Vine's Complete Expository Dictionary of Old and New Testament Words (Nashville: Thomas Nelson Inc., 1999), 66.

[11] O. Otite, "Conflicts, Management, Resolution and Transformation." In: Community Conflicts in Nigeria: Management, Resolution and Transformation (Ibadan: Safari Books, 1999), 1.

[12] O. Imasogie, "Managing Crisis within the Church". In: Managing Crisis Within the Church: A Collection of Message. G.A. Alawode (ed.) (Ibadan: Signal Education Service Ltd., 1989), 5

[13] M.O. Adeniyi, "Religion and Conflict Resolution: An Islamic Approach." In: M.T. Yahya, et al. (ed.), Issues in the Practice of Religion in Nigeria (Jos : NASR, 2006), 204.

[14] C.O. Imo, Religion and he Unity of the Nigerian Nation (n.p: Wilkell International, 1995), 21-22.

[15] Adeniyi, 204

[16] The Punch, 22 April, 1999,1-2

[17] Adeniyi, 207

[18] Adeniyi, 206-207

[19] C.U. Mamus, "Reading Matthew 18:15-22 in the context of Conflict Resolution in Nigeria." In: J.S. Ukpong (ed.), African Interpretation of the Bible: A Reader (Uyo: Uniuyo, 2006, unpublished), 31.

[20] F. Coulmas, The Blackwell Encyclopedia of Writing Systems (Wiley: Blackwell, 1999), 1.

[21] BBC News. http://news.bbc.co.uk.

[22] P.K. Austine, One Thousand Languages: Living, Endangered and Lost (California: University Press, 2009), 64.

[23] Al Jazeera, (2009-07-27). http://english.adjazeera.net/news/Africa.

[24] J. Shiklam, "Jos Crisis - CAN Condemns Bauchi Expulsion of Plateau Indigenes." Daily Champion,18 February, 2010.

[25] J. A. Onimhawo and P. O. O. Ottuh, "Religious Extreemism: A Challenge to National Unity and Development".The Nigeria Journal of Christian Studies, 2 and 3(2007): $54-66$.

[26] Onimhawo and Ottuh.

[27] K. Larewaju, "Soyinka Blames World Crisis on Religious Intolerance". The Vanguard, 22 October, 2007 cf. Umejesi, I. O. "Rule of Law as A Panacea to Religious Crisis in Contemporary Nigeria:. In: A. K. Chepkwony, and P. M. J. Hess (eds.), Human Views on God, Variety Not Monotony (Kenya: Moi University Press, 2010), 233 - 239.

[28] G. A Mohammed, "Religious Intolerance: the Islamic Concept". Iroro: A Journal of Arts, vol. 10. No. 1 \& 2 (2007).

[29] Onimhawo and Ottuh, 61.

[30] Mamus, 32.

[31] W.D. Davis, The Setting of the Sermon on the Mount (Cambridge: University Press, 1964), 316-366.

[32] Mamus, 32 .

[33] W.D. Davis, and D.C. Allison, The Gospel According to St. Matthew (Edinburgh: ICC Clark, 1987), 258.

[34] F.R. Youngblood, F.F. Bruce, and R.K. Harrison, (eds), Nelson's New Illustrated Bible Dictionary (Nashville: Thomas Nelson, 1995), 617-623

[35] P. Ighovojah and P.O. Okumagba, "Nigerian Norms and Values". In: B.E. Uweru and J.O. Ubrurha (eds.), Culture Nigerian People and Culture, Vol. 3 (Abraka: GSD. Delta State University, 2000), 40.

[36] W.E. Vine, Vine Concise Dictionary of the Bible (Nashville: Thomas Nelson, Inc., 1999), 251.

[37] Ighovojah and Okumagba, 40-45.

[38] O. Odeh, "Utilization of Christianity and Islam for Unity in Nigeria". In: M. T. Yahya (ed.), Issues in the Practice of Religious in Nigeria (Ilori: NASR, 2006), $92-102$.

[39] R.J. Schreiter, The Ministry of Reconciliation: Spirituality and Strategies (Maryknoll: Orbis Books, 1998), 13.

[40] O. Umejesi, "Rule of Law as A Panacea to Religious Crisis in Contemporary Nigeria". In: A. K. Chepkwony, and P. M. J. Hess (eds.), Human Views on God, Variety Not Monotony (Kenya: Moi University Press, 2010), 237. 